\title{
Formation of copper sulfides on polypropylene matrix using various reducing agents
}

\author{
Kamilè Vonžodaitė, \\ Eglè Balčiūnaitè ${ }^{*}$ \\ Rasa Alaburdaitè, \\ Edita Paluckienè \\ Kaunas University of Technology, \\ Radvilenu Rd. 19, \\ 50254 Kaunas, Lithuania
}

\begin{abstract}
Layers of copper sulfides, $\mathrm{Cu}_{\mathrm{x}} \mathrm{S}$, on the surface of a polypropylene film were formed by the sorption-diffusion method using two reducing agents - hydroquinone and hydroxylamine sulfate. The formed copper sulfide layers were investigated by UV/VIS, X-ray diffraction (XRD) and water contact angle measurements (WCA). The investigations confirmed that a layer of nonstoichiometric copper sulfide was formed on the surface of the polypropylene film. The water contact angle measurements revealed the change in adhesive properties of the samples after each treatment stage.
\end{abstract}

Keywords: polypropylene, copper sulfide layer, water contact angle, X-ray diffraction, UV-VIS

\section{INTRODUCTION}

Copper sulfides have the ability to form various stoichiometries, at least five phases of which are stable at room temperature: covellite $(\mathrm{CuS})$, anilite $\left(\mathrm{Cu}_{1.75} \mathrm{~S}\right)$, digenite $\left(\mathrm{Cu}_{1.8} \mathrm{~S}\right)$, djurleite $\left(\mathrm{Cu}_{1.95} \mathrm{~S}\right)$ and chalcocite $\left(\mathrm{Cu}_{2} \mathrm{~S}\right)$. Depending on the stoichiometric composition, these copper sulfides can be insulators, semiconductors, conductors and superconductors [1, 2]. Their unique properties determine promising applications in numerous fields, such as solar control coatings and photovoltaic devices, polarizers of infrared radiation [3], chemical sensors [4] 8], optical filters [9] 11], superionic materials [12-16], superconductors [17] and catalysts [18]. Due to their unique optical and electrical properties, they can also be applied in thin films and composite materials [19].

Usage of polymer films, coated with electroconductive layers, has been increasing in the past years due to their elasticity, resistance against corrosion and low toxicity. Electrically conductive $\mathrm{Cu}_{\mathrm{x}} \mathrm{S}$ layers on polymers can be prepared by methods of vacuum evaporation, activated reactive evaporation [20], electroless deposition [21], suc-

\footnotetext{
${ }^{*}$ Corresponding author. Email: egle.balciunaite@ktu.lt
}

cessive ionic layer adsorption and reaction (SILAR) [22], chemical bath deposition [17, 23] and sorption-diffusion methods [24]. By the last method, the surface of a polymer is initially treated by a sulfurization agent: sodium polysulfides [25], polythionic acids and polythionates [26- 35 ], sulfur in a carbon disulfide solution [36], thiourea solutions [37] and sulfur [38]. In the second stage sulfurized polymer films are treated with an aqueous $\mathrm{Cu}$ (I/II) salt solution [25, 29, 39].

Polypropylene (PP) is resistant toward many organic and inorganic solvents and is chemicals constructive plastic, which is characterized by good dielectric properties 40 , 41]. PP, out of all other plastics, has very low density (about $900 \mathrm{~kg} / \mathrm{m}^{3}$ ) and an excellent resistance to high temperatures. Also, the global consumption of polypropylene means that the plastic has diverse applications.

The aim of this study was to form copper sulfide layers on polypropylene films using different reducing agents, investigate and compare their properties by UV/VIS, X-ray diffraction (XRD) and water contact angle measurements. Firstly, polymers were pre-treated for surface activation in a $\mathrm{KMnO}_{4} / \mathrm{HCl}$ solution, and subsequently $\mathrm{Cu}_{\mathrm{x}} \mathrm{S}$ layers on $\mathrm{PP}$ were prepared by the sorption-diffusion method using a thiourea solution as a sulfuring agent. 


\section{EXPERIMENTAL}

Copper sulfide layers were formed on $15 \times 70 \mathrm{~mm}, 150 \mu \mathrm{m}$ thickness samples of polypropylene (PP). Only fresh reaction solutions, prepared using distilled water and analytically pure reagents, were used. The formation of $\mathrm{Cu}_{\mathrm{x}} \mathrm{S}$ layers on PP was carried out in a glass reactor using the sorptiondiffusion method in atmospheric pressure conditions.

The hydrophobic PP requires an initial surface pretreatment. First, the PP samples were cleaned ultrasonically for $10 \mathrm{~min}$ at $20^{\circ} \mathrm{C}$ in acetone and then in ethanol to remove organic material, and dried in an oven for $1 \mathrm{~h}$ at $50^{\circ} \mathrm{C}$. The average weight loss was $0.19 \mathrm{~g} / \mathrm{m}^{2}$. Then the PP samples were held in an oxidizing solution $\left(0.05 \mathrm{M} \mathrm{KMnO}_{4} / 2 \mathrm{M}\right.$ $\mathrm{HCl})$ at $60^{\circ} \mathrm{C}$ temperature for 2 to $5 \mathrm{~h}$ to enhance their adhesive properties [42].

After the pre-treatment stage, the PP samples were sulfurized for $1-5 \mathrm{~h}$ in an acidic $\left(\mathrm{HCl} \mathrm{1:1} \mathrm{H}_{2} \mathrm{O}\right)$ solution of $3 \mathrm{M}$ thiourea $\left(\left(\mathrm{NH}_{2}\right)_{2} \mathrm{CS}\right)$ with a $0.005 \mathrm{M}$ ammonium persulfate $\left(\left(\mathrm{NH}_{4}\right)_{2} \mathrm{~S}_{2} \mathrm{O}_{8}\right)$ additive at $60^{\circ} \mathrm{C}$.

$\mathrm{Cu}_{\mathrm{x}} \mathrm{S}$ layers were formed with $0.4 \mathrm{M} \mathrm{CuSO}_{4}$, using $0.1 \mathrm{M}$ hydroquinone $\left(\mathrm{C}_{6} \mathrm{H}_{4}(\mathrm{OH})_{2}\right)$ or hydroxylamine sulfate $0.03 \mathrm{M}\left(\left(\mathrm{NH}_{2} \mathrm{OH}\right)_{2} \mathrm{H}_{2} \mathrm{SO}_{4}\right)$ with ammonia $3.2 \mathrm{M}\left(\mathrm{NH}_{3} \cdot \mathrm{H}_{2} \mathrm{O}\right)$ as reducing agents for $1-20 \mathrm{~min}$ at $80^{\circ} \mathrm{C}$. Afterwards, the PP films were thermally treated in an oven for $1 \mathrm{~h}$ at $80^{\circ} \mathrm{C}$.

The X-ray diffraction analysis of the samples was performed on a D8 Advance diffractometer (Bruker AXS, Karlsruhe, Germany) operating at $40 \mathrm{kV}$ tube voltage and $40 \mathrm{~mA}$ tube current. The X-ray beam was filtered with a $\mathrm{Ni}$ $0.02 \mathrm{~mm}$ filter to select the $\mathrm{Cu} \mathrm{Ka}$ wavelength. The diffraction patterns were recorded in the Bragg-Brentano geometry using a fast counting detector Bruker LynxEye based on the silicon strip technology. The samples were scanned over the range $2 \theta=3-60^{\circ}$ at a scanning speed of $6^{\circ} \mathrm{min}^{-1}$ using a coupled two theta/theta scan type. The peaks obtained were identified on the basis of those available in the PDF-2 database [43].

The PP samples with sulfur and $\mathrm{Cu}_{\mathrm{x}} \mathrm{S}$ layers were characterized by UV spectroscopy (190-500 nm) using a UV/VIS spectrometer SPECTRONIC ${ }^{\circledR}$ GENESYS8 (Perkin Elmer, USA).

Water contact angle (WCA) measurements were carried out at room temperature and atmospheric pressure using an optical measuring equipment - Theta Lite Optical Tensiometer TL100 (Biolin Scientific, Finland). A distilled water drop was released onto the test substrate surface using a syringe. The drop geometry was acquired by a numerical camera and transmitted to a computer workstation to calculate the WCA value. All WCA data were averaged from two measurements. Instrument specifications were the following: measuring range varied from $0^{\circ}, \mathrm{mN} / \mathrm{m}$ to $180^{\circ}$, $\mathrm{mN} / \mathrm{m}$ with an accuracy of $\pm 0.1^{\circ}, \mathrm{mN} / \mathrm{m}$. A USB3 digital camera was used. A light source was created with the LED based background lighting.

\section{RESULTS AND DISCUSSION}

Visual inspection. Colour intensity of the PP films with $\mathrm{Cu} S$ layers is directly proportional to the treating time (Fig. 1). Dark brown $\mathrm{Cu}_{\mathrm{x}} \mathrm{S}$ layers were formed using hydroquinone, whereas dark brown layers with a reddish tint were created using hydroxylamine sulfate as a reducing agent.

$X R D$ analysis was applied to determine the structure, composition and physical properties of materials. The data of XRD analysis of the modified PP (Table 1) have shown that beta-sulfur and sulfur $\mathrm{S}_{18}$ dominate in sulfurized PP, chalcosine low, $\mathrm{Cu}_{2} \mathrm{~S}$; djurleite, $\mathrm{Cu}_{1,9375} \mathrm{~S}$ and $\mathrm{Cu}_{31} \mathrm{~S}_{16}$ in the samples using hydroquinone and hydroxylamine sulfate as a reducing agent [43].

UV/VIS absorption maxima in the spectrum of PP sulfurized for $5 \mathrm{~h}$ were as follows: peak at $240 \mathrm{~nm}$, and shoulders at 250 and $275 \mathrm{~nm}$ (Fig. 2, Curve 2). The spectra of PP films with copper sulfides were formed using hydroquinone display shoulders at 305, 320 and $325 \mathrm{~nm}$ (Fig. 2, Curve 3), and in the ones formed using hydroxylamine sulfate there are additional peaks at 360 and $405 \mathrm{~nm}$ (Fig. 2, Curve 4).

The UV/VIS analysis has shown that absorbance of the PP films increases after sulfurizing and coating with copper sulfides. The PP films treated using hydroquinone have a lower absorbance value (Fig. 2, Curve 3) than those treated with hydroxylamine sulfate as a reducing agent (Fig. 2, Curve 4).

The purpose of the contact angle investigation was to study the wetting when a solid and a liquid interact. Small contact angles (lower than $90^{\circ}$ ) correspond to high wettability, while large contact angles (greater than $90^{\circ}$ ) correspond to low wettability.

The investigation has shown that the PP films have gone through significant surface processing, because water contact angle values increased from $90^{\circ}$ of the non-treated PP films to $130^{\circ}$ of the treated PP films (Table 2).

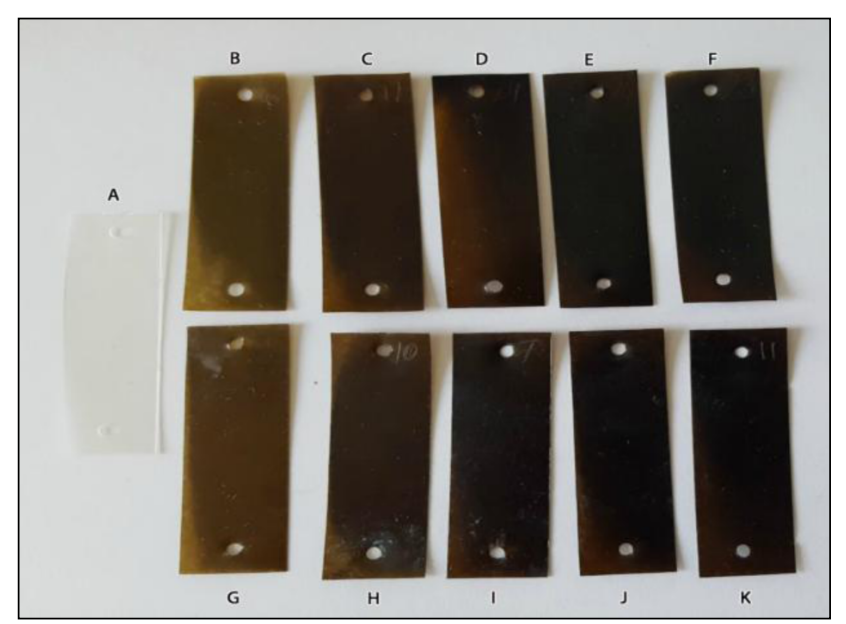

Fig. 1. Photos of the samples treated in $\mathrm{Cu}(\mathrm{l} / \mathrm{ll})$ solution for different duration: non-treated (A); using hydroquinone as a reducing agent: treated for $1 \mathrm{~min}(B)$, $3 \mathrm{~min}(\mathrm{C}), 6 \mathrm{~min}(\mathrm{D}), 9 \mathrm{~min}(\mathrm{E}), 12 \mathrm{~min}(\mathrm{~F})$; using hydroxylamine sulfate as a reducing agent: $1 \mathrm{~min}(\mathrm{G}), 3 \mathrm{~min}(\mathrm{H}), 6 \mathrm{~min}(\mathrm{I}), 9 \mathrm{~min}(\mathrm{~J}), 12 \mathrm{~min}(\mathrm{~K})$ 
Table 1. d-Spacing, angle values and their respective planes for $\mathrm{Cu}_{\mathrm{x}}$ Slayers

\begin{tabular}{|c|c|c|c|}
\hline \multirow{2}{*}{ Standard d-spacing (A) } & \multicolumn{2}{|c|}{ Observed } & \multirow{2}{*}{$\boldsymbol{h} \boldsymbol{k} /$ planes } \\
\hline & d-spacing & Angle (2q) & \\
\hline \multicolumn{4}{|c|}{ Polypropylene [00-050-2397] } \\
\hline 6.32 & 6.32 & 14.00 & 110 \\
\hline 5.25 & 5.26 & 16.85 & 040 \\
\hline 4.78 & 4.80 & 18.47 & 130 \\
\hline 4.20 & 4.22 & 21.01 & 111 \\
\hline 4.07 & 4.07 & 21.81 & -131 \\
\hline \multicolumn{4}{|c|}{ beta-sulfur S [34-941] } \\
\hline 4.06 & 4.07 & 21.84 & -202 \\
\hline \multicolumn{4}{|c|}{ Sulfur $S_{18}[72-409]$} \\
\hline 6.32 & 6.34 & 13.96 & 011 \\
\hline 5.29 & 5.27 & 16.81 & 400 \\
\hline 4.80 & 4.81 & 18.43 & 410 \\
\hline \multicolumn{4}{|c|}{ Chalcosine low $\mathrm{Cu}_{2} \mathrm{~S}$ [83-1462] } \\
\hline 6.37 & 6.35 & 13.93 & $-211 / 111$ \\
\hline 4.80 & 4.79 & 18.50 & $-302 / 102$ \\
\hline \multicolumn{4}{|c|}{ Djurleite $\mathrm{Cu}_{1.9375} \mathrm{~S}$ [71-1383] } \\
\hline 4.77 & 4.79 & 18.50 & $-402 / 402$ \\
\hline 4.08 & 4.07 & 21.84 & $422 /-512$ \\
\hline \multicolumn{4}{|c|}{ Djurleite $\mathrm{Cu}_{31} \mathrm{~S}_{16}[42-564]$} \\
\hline 4.07 & 4.09 & 21.72 & -512 \\
\hline
\end{tabular}

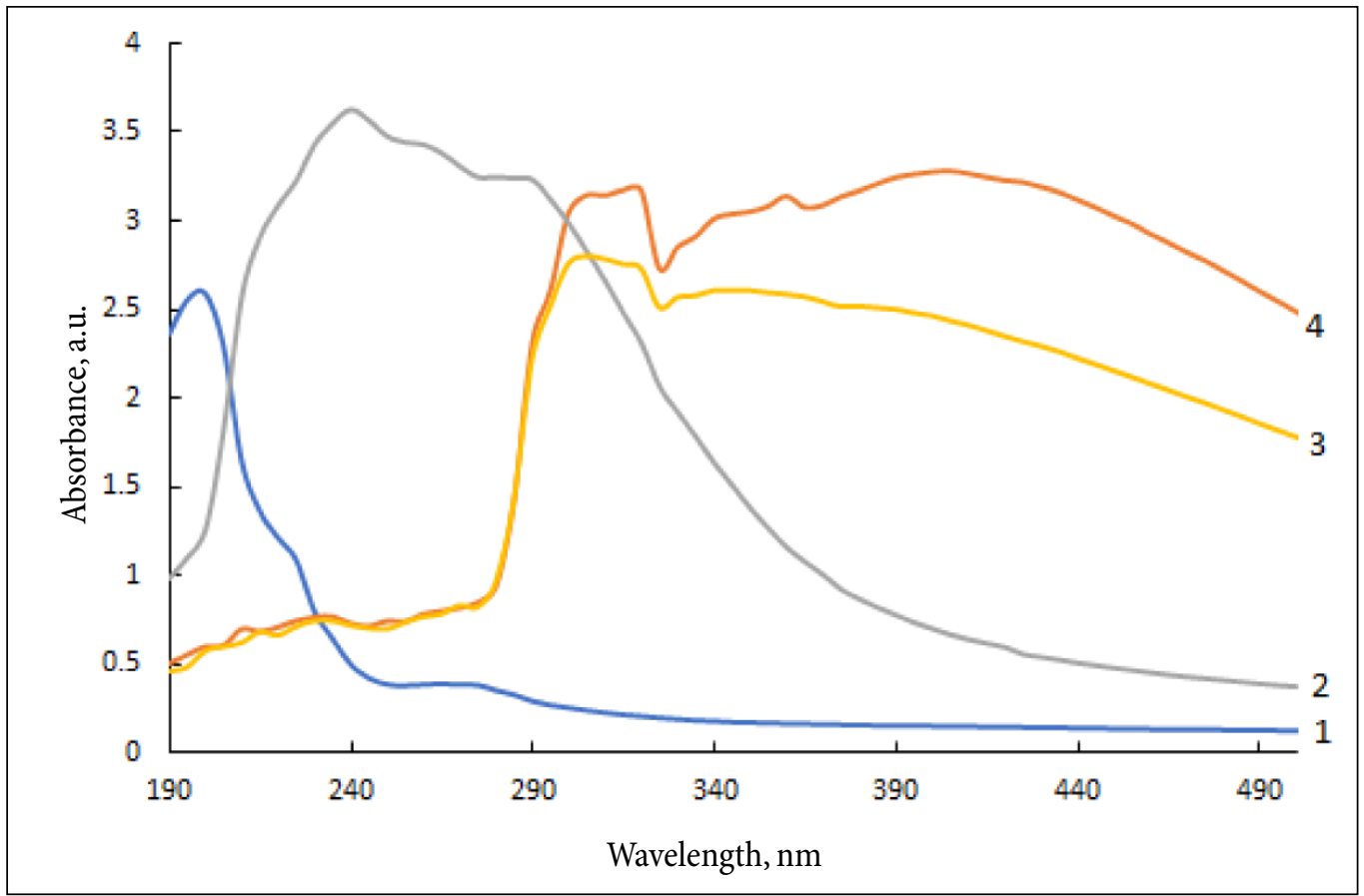

Fig. 2. UV/VIS spectra of the PP films: non-treated (1), oxidized for $5 \mathrm{~h}$ and sulfurized for $5 \mathrm{~h}$ (2), Cu $\mathrm{S}$ formed with hydroquinone as a reducing agent for $12 \mathrm{~min}(3), \mathrm{Cu}_{\mathrm{x}} \mathrm{S}$ formed with hydroxylamine sulfate as a reducing agent for $12 \mathrm{~min}$ (4) 
Table 2. Water contact angle

\begin{tabular}{c|c|c|c|c|c|c}
\hline Name & Non-treated & Pre-treated & Oxidized & Sulfurized & $\begin{array}{c}\mathrm{Cu}_{\mathrm{x}} \mathrm{S} \text { formed } \\
\text { with hydroquinone }\end{array}$ & $\begin{array}{c}\mathrm{Cu}_{\mathrm{x}} \mathrm{S} \text { formed } \\
\text { with hydroxylamine sulfate }\end{array}$ \\
\hline $\begin{array}{c}\text { WCA } \\
\text { (average) }\end{array}$ & $90.00^{\circ}$ & $83.02^{\circ}$ & $92.00^{\circ}$ & $103.52^{\circ}$ & $131.11^{\circ}$ & $130.82^{\circ}$ \\
\hline
\end{tabular}

The results showed that the pre-treated films had the lowest water contact angle. During all other treatment stages, starting from oxidation, the wettability increases (Fig. 3). The comparison of the samples with $\mathrm{Cu}_{\mathrm{x}} \mathrm{S}$ layers formed using different reducing agents has revealed that the highest contact angle was achieved in the case of treatment with hydroquinone. sulfur $\mathrm{S}$, sulfur $\mathrm{S}_{18}$, chalcosine low $\mathrm{Cu}_{2} \mathrm{~S}$, djurleite $\mathrm{Cu}_{1,9375} \mathrm{~S}$ and $\mathrm{Cu}_{31} \mathrm{~S}_{16}$. The UV/IVS results showed that the absorption values were lower when hydroquinone was used as a reducing agent. Absorption increased with increasing the time of treating with $\mathrm{CuSO}_{4}$. The results of the water contact angle measurement showed a significant change in the PP film wettability from the non-treated films to the films
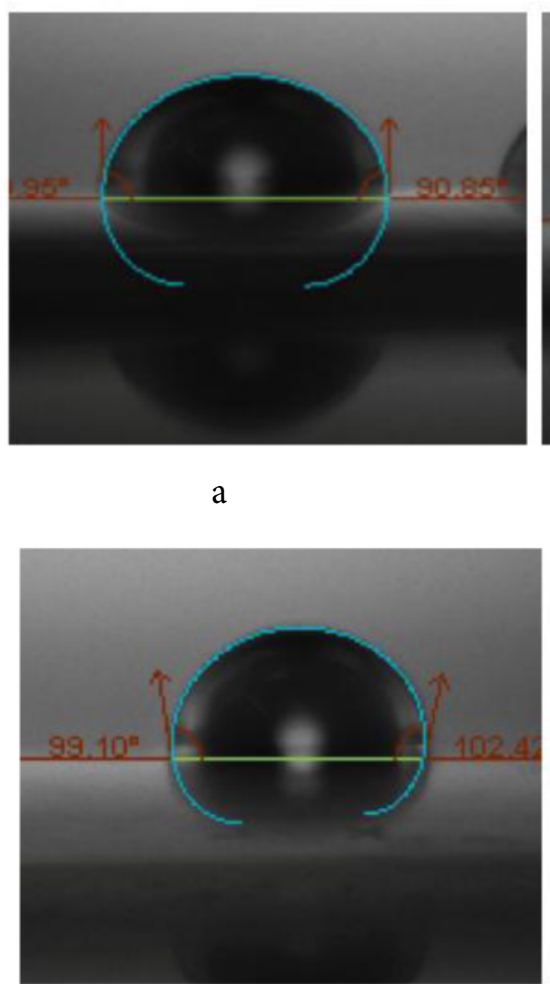

d

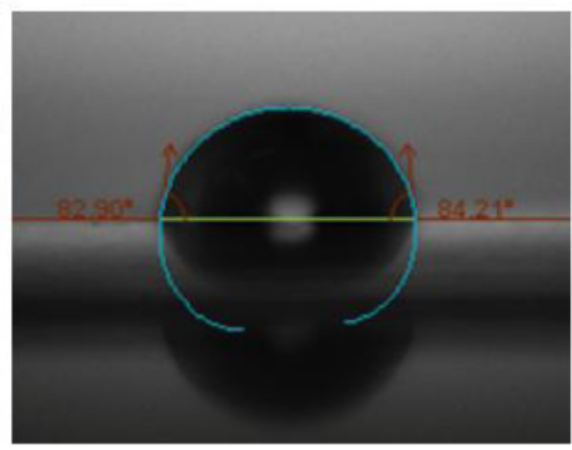

$\mathrm{b}$

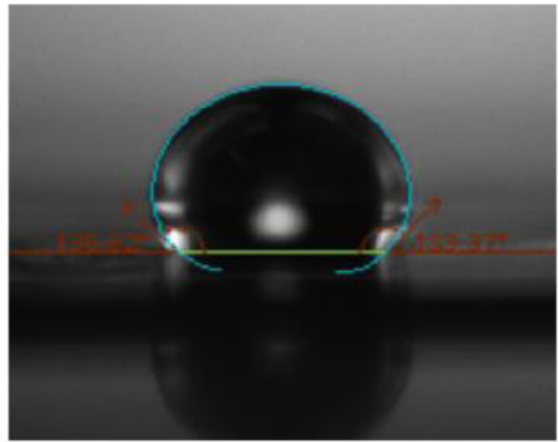

e
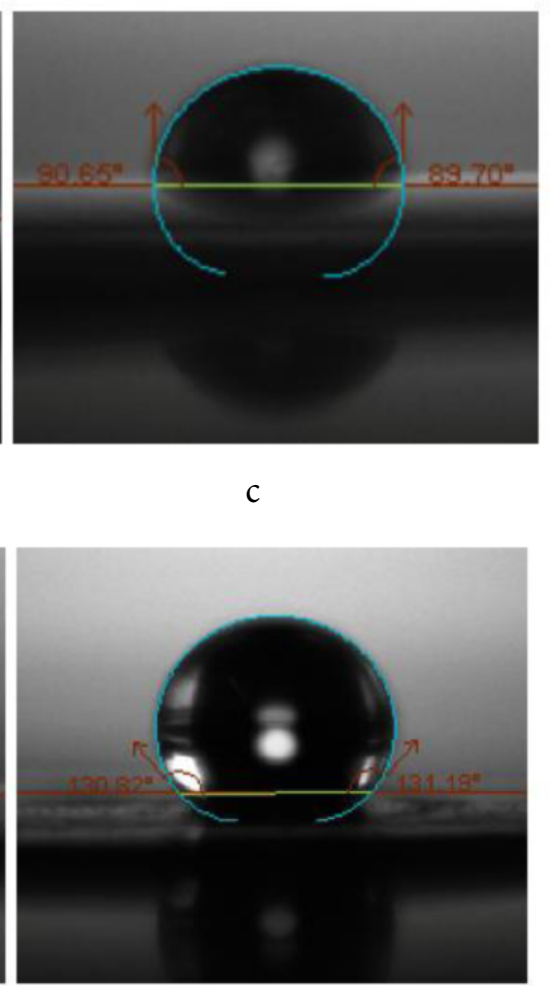

Fig. 3. Photos of the contact angle measurements of the PP films: non-treated (a), pre-treated (b), oxidized (c), sulfurized (d), Cu S formed with hydroquinone as a reducing agent for $12 \mathrm{~min}$ (e), Cu $\mathrm{S}$ formed with hydroxylamine sulfate as a reducing agent for $12 \mathrm{~min}$ (f)

\section{CONCLUSIONS}

The colour intensity of PP increased with increasing the treatment duration in the $\mathrm{Cu}(\mathrm{I} / \mathrm{II})$ solution and depended on the used reducing agent. Dark brown and black $\mathrm{Cu} \mathrm{S}$ layers were formed using hydroquinone, whereas dark brown layers with a reddish tint were created using hydroxylamine sulfate as a reducing agent. The XRD analysis has shown what phases were formed on the PP film. The main ones that dominated throughout all of the samples, treated with $\mathrm{CuSO}_{4}$ and reducing agents, were beta- which had copper sulfide layers on them. The PP films with $\mathrm{Cu}_{\mathrm{x}} \mathrm{S}$ showed lower wettability than the non-treated samples.

Received 14 May 2018

Accepted 27 June 2018

\section{References}

1. H. M. Pathan, J. D. Desai, C. D. Lokhande, Appl. Surf. Sci., 202(1-2), 47 (2002) 
2. I. Popovici, L. Isac, A. Duta, Bull. Transilv. Univ. Braşov, 2(51), 193 (2009).

3. M. T. S. Nair, P. K. Nair, J. Phys. D: Appl. Phys., 24(3), 450 (1991).

4. U. Shamraiz, R. A. Hussain, A. Badshah, J. Solid State Chem., 238, 25 (2016).

5. Z. Q. Mamiyev, N. O. Balayeva, Mendeleev Commun., 26, 235 (2016).

6. S. Zhang, H. Zhong, C. Ding, Anal. Chem., 80(19), 7206 (2008).

7. A. Galdikas, A. Mironas, V. Strazdiene, A. Setkus, I. Ancutiene, V. Janickis, Sens. Actuators, B, 67(1-2), 76 (2000).

8. T. Fu, Electrochim. Acta, 112(1), 230 (2013).

9. M. Mousavi-Kamazani, Z. Zarghami, M. Salavati-Niasari, J. Phys. Chem. C, 120(4), 2096 (2016).

10. H. J. Kim, J. H. Kim, CH. S. S. Pavan Kumar, et al., J. Electroanal. Chem., 739, 20 (2015).

11. M. T. S. Nair, L. Guerrero, P. K. Nair, Semicond. Sci. Tech., 13(10), 1164(1998).

12. M. X. Guo, S. W. Bian, F. Shao, S. Liu, Y. H. Peng, Electrochim. Acta, 209, 486 (2016).

13. Y. Ren, H. Wei, B. Yang, J. Wang, J. Ding, Electrochim. Acta, 145, 193 (2014).

14. C. J. Raj, B. C. Kim, W. J. Cho, W. G. Lee, Y. Seo, K. H. Yu, J. Alloys Compd., 586, 191 (2014).

15. M. K. Balapanov, I. B. Zinnurov, U. K. Mukhamedyanov, Russ. J. Electrochem., 43, 585 (2007).

16. M. Saranya, R. Ramachandran, E. J. J. Samuel, S. K. Jeong, A. N. Grace, Powder Technol., 279, 209 (2015).

17. R. S. Mane, C. D. Lokhande, Mater. Chem. Phys., 65(1), 1 (2000).

18. H. Ren, W. Xu, S. Zhu, Z. Cui, X. Yang, A. Inoue, Electrochim. Acta, 190, 221 (2016).

19. F. A. Sabah, N. M. Ahmed, Z. Hassan, H. S. Rasheed, Procedia Chem., 19, 15 (2016).

20. I. Grozdanov, M. Najodski, J. Solid State Chem., 114(2), 469 (1995).

21. Y. H. Chen, C. Y. Huang, F. D. Lai, M. L. Roan, K. N. Chen, J. T. Yeh, Thin Solid Films, 517(17), 4984 (2009).

22. H. M. Pathan, J. D. Desai, C. D. Lokhande, Appl. Surf. Sci. 202, 47 (2002).

23. A. Žebrauskas, Chem. Technol., 1(3), 39 (1996).

24. R. Alaburdaite, E. Paluckiene, S. Grevys, Chalcogenide Lett., 13(12), 529 (2016).

25. A. Zebrauskas, R. Spirikavicienė, M. Baranauskas, J. Adhes. Sci. Technol., 4, 25 (2012)

26. R. Maciulevičius, V. Janickis, R. Ivanauskas, Chemija, 11(4), 141 (2000).

27. V. Janickis, R. Maciulevicius, R. Ivanauskas, I. Ancutiene, Mater. Sci.-Poland, 23(3), 715 (2005).

28. I. Ancutiene, V. Janickis, R. Ivanauskas, Appl. Surf. Sci., 252(12), 4218 (2006).

29. I. Ancutiene, V. Janickis, R. Ivanauskas, R. Stokiene, N. Kreiveniene, Polish J. Chem., 81, 381 (2007).

30. R. Ivanauskas, V. Janickis, I. Ancutienè, R. Stokienè, Cent. Eur. J. Chem., 7(4), 864 (2009).

31. R. Ivanauskas, V. Janickis, Prog. Colloid Polym. Sci., 116, 134 (2000).
32. V. Janickis, Polythionates, Monography, Technology, Kaunas (2006).

33. N. Petrašauskienè, V. Janickis, Chemija, 22(1), 25 (2011).

34. V. Krylova, R. Ivanauskas, Mater. Sci-Medzg., 13(2), 127 (2007).

35. V. Janickis, N. Petrašauskienè, Chemija, 28(4), 214 (2017).

36. J. Zukauskaite, V. Janickis, I. Ancutiene, Chem. Technol. 5(26), 36 (2002).

37. A. Danilevicius, S. Grevys, J. V. Grazulevicius, V. Grazuleviciene, Acta Chim. Slov., 52(3), 503 (2005).

38. R. Alaburdaite, S. Grevys, E. Paluckiene, Mater. Sci.-Medzg., 17(4), 399 (2011).

39. R. Alaburdaite, E. Paluckiene, Chalcogenide Lett., 15(3), 139 (2018).

40. M. Noeske, J. Degenhardt, S. Strudthoff, U. Lommatzsch, Int. J, Adhes. Adhes., 24(2), 171 (2004).

41. Y. H. Choi, J. H. Kima, K. H. Paek, W. T. Ju, Y. S. Hwang, Surf. Coat. Technol., 193(1-3), 319 (2005).

42. S. L. Favaro, A. F. Rubira, E. C. Muniz, E. Radovanovic, Polym. Degrad. Stab., 92, 1219 (2007).

43. PDF-2 International Centre for Diffraction Data [https:/www. icdd.com].

Kamilè Vonžodaitė, Eglè Balčiūnaitė, Rasa Alaburdaitė, Edita Paluckienè

\section{VARIO SULFIDŲ SLUOKSNIŲ SUDARYMAS ANT POLIPROPILENO MATRICOS NAUDOJANT SKIRTINGUS REDUKTORIUS}

Santrauka

$\mathrm{Cu}_{\mathrm{x}} \mathrm{S}$ sluoksniai ant polipropileno plèvelès buvo sudaromi sorbcijos-difuzijos būdu, naudojant du reduktorius - hidrochinoną ir hidroksilamino sulfatą. Atlikta sudarytu sluoksnių rentgeno difrakcinè analizè (XRD), vandens kontaktinio kampo (vilgumo) matavimai (WCA) ir užrašyti UV / VIS spektrai. Proceso metu po kiekvienos operacijos vandens kontaktinis kampas kito. Tyrimai patvirtino, kad ant polipropileno matricos buvo gauti nestechiometriniai vario sulfido sluoksniai. 
